OLEG RATUSHNYAK

$P h D$ in historical sciences, Kuban State University, Department of Modern, Contemporary History and International Relations, Associate Professor

\title{
COSSACK DIASPORA AS SOCIOHISTORIC PHENOMENON: FORMATION, MIGRATION AND ACTIVITIES
}

The Cossack émigré as a socio-historic phenomenon was created like result of the emigration of a part of the Cossacks after the defeat of the White movement in the Civil war in Russia. The Cossacks of the south-east part of the European Russia emigrated mostly to the West. The main countries of the Cossack emigrants' settlement initially became Turkey and Greece, later Bulgaria, Germany, Poland, France, Czechoslovakia, Yugoslavia. Members of the Cossack forces of the Asian Russia were going to the East. Most of them were placed in China, less in Australia. Total amount of the Cossacks abroad was about 100 thousand people.

The main reason for Cossacks to leave abroad was the Civil war. However the decision motives were different. Some Cossacks emigrated fearing repressions by the Soviet authorities. Other Cossacks went abroad being influenced by the overall spirit. And some of them emigrated in order to reunite with their families and relatives.

Not all Cossacks who had gone abroad were implacably set against the Soviet Russia. It is being proved with the repatriation process (it was started immediately after the emigration) which resulted coming back home of almost half of the Cossack emigrants. Partly it was conducted by the policy of the Soviet government on the Cossack emigrants. Its content was concluded in effort to tear the most part of the Cossacks from the rest of the White émigré and return them to their homeland. This action was taken by the Soviet authorities in order to weaken the counter-revolutionary camp.

In course of time the main centers of the Cossack Diaspora became Bulgaria, Yugoslavia, France, Czechoslovakia and China. The Cossack residence had its own distinctive features in each of these countries. Thus, in Bulgaria and Yugoslavia there were mainly the Cossack military units. Belgrade and Prague were the cultural centers of the Cossack Diaspora. However if in Yugoslavia the monarchist circles of the Russian (including Cossack) emigration were welcomed, in Czechoslovakia more loyal were being treated the émigré organizations and persons with Socialist Revolutionary views. This was firstly connected with the inner political situation in these countries. The Cossack emigrants in China had the most difficult life. That was explained by the large cultural and linguistic difference between the Cossacks and local population, and also by the difficult social-economic conditions of their existence in country.

In most countries many Cossacks were working in agricultural sphere. It was more particular thing for Czechoslovakia. In Bulgaria the emigrants' labor was used mainly in mines and seaports, in Yugoslavia they worked in the construction of railways and highways. In France and China the Cossack emigrants worked mainly as civilian farm workers and in cities they could be found in all spheres of urban infrastructure. 
The part of the Cossacks in a variety of reasons fell under assimilation. The fastest process of assimilation was being observed in Bulgaria, Czechoslovakia and Poland. It was firstly connected with the presence of Slavic population of these countries which was close to the Cossacks in cultural aspect. The assimilation was also facilitated by the fact that almost $90 \%$ of the Cossack emigrants were men many of which were unmarried. They were settling abroad, marrying local women and gradually losing their traditions and taking local customs.

Abroad the Cossacks created a number of cultural and socio-political organizations. The first of them contributed to the consolidation of the Cossack emigrants. The second ones, though claiming the unification of the Cossack forces abroad, in fact represented political discordance and dissent among the Cossacks. Among the Cossacks who had left abroad there were monarchists, cadets, socialistrevolutionaries of different kinds. The leaders and active members of various political Cossack organizations were mainly those persons who led active social and political actions even before emigration period. The most part of the Cossacks was apolitical and inert. This was mostly conducted by the difficulties which accompanied the life of emigrant.

Despite the difficulties of the emigrant life and political discordance (and maybe thanks to these factors) the Cossack emigrants were trying to save their own culture and traditions far away from their homeland. This let them save their identity, not to dissolve in the environment of the Russian emigration and not to assimilate with the local population.

The new stage in the development of the Russian Cossacks abroad was the World War II. During the war the conditions of the Cossack existence in most of countries significantly changed. The Cossack
Diaspora expanded with new members. Most of them were Cossacks who had left the USSR together with the retreating German troops and subsequently stayed abroad.

Also the geography of the Cossack settlement changed. The most of Cossacks moved from China to Australia. While Cossacks who had settled in Europe mostly moved to the USA, Canada and Latin America.

The targets of the main part of the Cossack emigrants also changed. Before the World War II most Cossacks lived with hope to return to their homeland. It explained their desire to settle as close to the Russian boundaries as possible, and desire to preserve their way of life. After the World War II the hope of coming back home in fact ceased to exist. It was replaced with fear of returning to the "Soviet country of Stalin". In this regard the Cossack emigrants tried to go as far from the USSR as possible. Refusing the hope to come back home the Cossacks started to integrate more actively into the social structure of host societies. Almost all of them took the citizenship of those countries they had settled in. Before the World War II most Cossacks tried to preserve their cultural identity, their language and even tried to learn their children in their emigrant schools. And after the war many of them tried to give to their children foreign education, good knowledge of foreign language and bring them into the culture of host societies.

Though after the World War II the Cossack Diaspora seems to be less united and cohesive, still a certain part of the Cossack emigrants tried to be in touch with each other. It was largely contributed by preserved institute of "atamanstvo" and also by different socio-cultural and socio-political organizations of the Kuban Cossacks. Thanks to presence and preservation of these institutes at the 
Don and Kuban Cossacks they were able to continue as the centers of the Cossack Diaspora up to the present time.

The third stage in the history of the Cossack émigré began in the 1990s. It was caused by socio-political and socioeconomical changes in the USSR and its disruption. This stage was being characterized by two major trends. The first was the convergence of the foreign Cossacks with the relived Russian Cossacks, setting at first turn of the sociocultural contacts and connections. In the second place the new departure of the emigrants including Cossacks started in Russia. New emigrants in majority were aiming to integrate more quickly into the social structure of the host countries and occasionally used local members of the Cossack Diaspora. Sometimes these emigrants brought to the reanimation of the variety of socio-cultural organizations of the Cossacks abroad. Some of these organizations initiated the process of the revival of the Cossacks abroad and started to recover the connections between the Russian and abroad Cossacks.

We will consider in more detailed way the evolution and current state of the main institutions that had facilitated the Cossacks' adaptation abroad, preservation and development of the Cossack Diaspora.

Firstly it is the military organization of the Cossacks of Russia itself. Before the revolutionary events and the Civil War (1917-1920) the Cossack hosts of the Russian Empire represented the unique socio-political and socio-economic organisms that were organically built into the social class structure of the Russian monarchy. Although the process of creating the Cossack hosts was extremely controversial and ambiguous. The main contradiction was concluded in the fact that on the one hand the Cossacks often opposed the Russian monarchy, on the other hand some Cossacks served as a kind of border guards of the Russian Empire. The Cossacks have preserved this contradiction during all the $20^{\text {th }}$ century.

The desire of common Cossacks and atamans to preserve the military organization of the Cossack society was caused by several reasons. First the Cossack communities in majority initially originated and developed in form of military organization. Because of this the military structure mostly was one of the important components of the Cossack identity. Naturally its importance increased even more in the emigration. Second inside the Russian and the Cossack émigré it appeared the mechanism of some conservation of the image of prerevolutionary Russia with all its attributes and symbols in the people perception. And the military organization of the Cossacks was not the exception. Third the military organization of the Cossack communities was some unifying basis and unifying center of the Cossack emigrants.

Nowadays the Cossack organizations and communities both in Russia and abroad are still intensively using in their names such words like "Host", "Military". For example, the Kuban military Cossack community, the Kuban Host, the Union of the Cossack Hosts abroad etc.However these terms mostly have another meaning and their use is being determined by the desire to preserve some certain continuity and traditions with the former military Cossack structures.It is also connected with attempts to preserve maybe sometimes in a modified way the Cossack uniform, ranks and titles as belonging to the military organization.

The institute of atamanstvo (chieftainship) has been being integral and at the same time independent part of the Cossacks. Its importance and significance in the organization of the Cossack society abroad and in the subsequent functioning 
of the Cossack Diaspora are being proved by the fact that during the $20^{\text {th }}$ century more viable became those Cossack hosts which were able to preserve this institution of chieftainship abroad although in some transformed form. We can take for example the Kuban and the Don Cossack Hosts. The significance of the chieftainship in the life of the Cossack emigrants was demonstrated by the tension of the ataman elections abroad. This event to various extents affected the main part of the Cossack emigrants.

At the moment the atamanstvo has preserved its main features and functions: the ataman electivity, the leadership of the atamans and their representative functions.

The third traditional institution of the Cossack émigré was the village and farmstead form of the Cossack organization. The Cossack villages and farmsteads abroad were being created mainly in the places of their compact residence. In the areas of their highest concentration Don, Kuban, Terek, Ural and other Cossacks were founding their own (Don, Kuban, Terek, Ural etc.) villages and farmsteads. Sometimes those were the universal Cossack communities formed by the Cossacks of different Hosts.

Besides that the Kuban villages according to the decision of the Kuban Rada could include all the Kuban inhabitants both Cossacks and non-Cossacks. And in the Kuban village in Paris where lived Cossacks, non-Cossacks, Caucasians there was also an honorable Cossack - the lieutenant of the French army R. Pirc. Sometimes villages and farmsteads were being formed on a professional basis. These were different communities of the Cossack students, for example, the Cossack student village in Prague or the Cossack student farmstead in Sofia village. ${ }^{1}$

1 Ratushnyak O.V. The Kuban Cossacks in emigration (1920-1939) // Historical and socio-educational though. 2013. P. 39.
Initially villages and farmsteads were being created spontaneously. This fact also shows the importance of atamanstvo for the life of the Cossacks and adaptation abroad. Only after some time it was issued "The Regulation on the management of villages and farmsteads abroad". This document was proved by the chairman of the United Council of Don, Kuban and Terek the ataman of the Great Don Host A.P. Bogaevsky. The Regulation confirmed that the Cossack villages and farmsteads were being created "in order to unite and pull together all Cossacks abroad. The main targets of these organizations were legal and medical assistance, care for disabled, single women, children and unemployed, defense of the Cossack interests abroad and meeting their cultural and domestic needs". ${ }^{2}$ In general this institution contributed not only to the communication, adaptation and mutual help of the Cossacks, but also to the preservation of the Cossack customs, rituals and culture far away of their homeland.

Currently the Cossack villages and farmsteads almost everywhere and especially abroad exist in the form of public organizations and associations and their charters are guided by the laws of those states where they are registered. This legislation and also demands of the Cossack communities determine their main activity areas.

As it was already noted almost all main and significant for Cossacks institutions were being transformed during the process of the evolution of the Cossack community abroad. The Cossacks itself underwent the certain transformation. The researchers while defining the Cossacks as an object to study face difficult methodological problem - what are the Cossacks? Such problem is being

2 The State Archive of the Russian Federation. F. 6461. L. 1. F. 273. P. 14. 
faced also by the representatives of the Cossacks abroad (and in Russia too).

Different definitions of the Cossacks including several interpretations of their origins are introduced into the scientific turnover. One of the key issue in discussions about the nature of the Cossacks is concluded in dichotomy: is it ethnic community or military service class. Recognizing the Cossacks as an ethnic community creates new questions: is it separate ethnos, sub ethnos (ethnos in the process of its formation) or part of another ethnos (for example Russian). In turn recognizing the Cossacks as special (military service) class is complicated by recognition of the fact that among the Cossacks it is possible to distinguish the representatives of the other classes (nobility, clergy). More complicated becomes the problem of existence among the Cossack hosts of people belonging to the other ethnic groups.

Moreover even if we agree with the fact that "the oppositions of such diverse concepts like the Cossack ethnos and the Cossack class are futile and simply unscientific" it would not help us to solve the problem of defining the nature of the Cossacks.Because there immediately appear another questions: do Don, Kuban, Terek and other Cossacks belong to one ethnic community or to separate ethnic formations?

Moreover life itself withdrew this dichotomy in November 1917 when the Council of People's Commissars passed a decree "On the destruction of classes and civilian ranks". The class privileges and limitations were abolished. However it did not make life easier for the researches of the Cossack history in the post-revolutionary period in terms of determining the research object. And the

1 Trut V.P. The ethno-social characteristic of the Cossacks in the beginning of the XX century. // http:// dikoepole.com/2010/07/05/trut_kazachiy_izlom_01/ (29.03.2014) following events even more complicated this problem.

In the 1920s the Cossacks possessed at least a "double ethno social identity weakly identified by then analysis methods: socio-professional group and ethnic group". ${ }^{2}$

We will name some factors that influenced such important component of any social community (ethnic of socioprofessional) like self-consciousness and self-identity in relation to the Cossacks. First this is the repressive policy of the state and party organs of the Soviet regime against the most part of the Cossacks. This policy launched serious strike on the self-consciousness and self-identity of the Cossacks.

Another significant factor that influenced self-consciousness and selfidentity of the Cossacks was the process of "raskazachivanie" (liquidation of Cossacks as social group, class) which appeared both as objective socio-economical process and as deliberate policy of the Soviet government during the collectivization. More significantly this factor influenced the socio-professional identity of the Cossacks.

The third factor came out through the activities which at first glance were to promote the growth of self-consciousness and self-identity of the Cossacks. The thing is about the assignment in 1936 to a number of cavalry units a status of Cossack units. Considering the existing territorial principle of recruitment cavalry units they included not only natural Cossacks but also people who lived in the territories of former Cossack regions. As A.G. Masalov correctly noted "these circumstances much more weakened traditional fundamental identification characteristics of the Cossacks and complicated the

2 Baranov A.V. The actual issues of the geography of the settlement and identity of the Cossacks in the South of Russia in 1920s. // http://www.slavakubani.ru/ content/detail.php?ID=24796\&page=1 (30.03.2014) 
structure of the Cossack social community, increased its heterogeneous nature". ${ }^{1}$ After him "until the 80s of the XIX century the Russian Cossacks represented geographically disjoined heterogeneous and multi-religious social community...and historically predetermined commonness of cultural traditions was its group-forming factor". ${ }^{2}$

All these factors significantly influenced the self-consciousness and self-identity of the Cossacks who had been living in the USSR territory and further left for West with German troops.

The attempt of defining the nature of the Cossacks by analyzing its representatives abroad is being also difficult. The Cossacks abroad had been preserving the remnants of class ideas much longer than the Cossacks in Russia. It is firstly connected with such psychological phenomenon like some conservation in views of prerevolutionary Russia that was being noted both by the contemporaries of that time and by the following researchers. The ethnic component had taken exaggerated forms among the members of the Cossacks abroad. That resulted not only the independent tendencies and the claims for the independence of the Cossack lands and regions but also the appearance of such socio-political project like creation of Cossackia - the state of Cossacks.

Eventually there appeared some other trends which make the problem of determination of the Cossack nature more perplexed. For example, during the emigration some part of the Black Sea Cossacks identified themselves more often as Ukrainians. The Astrakhan Cossack

1 Masalov A.G. The Russian Cossacks: sociopolitical institutionalization in modern conditions: thesis of Grand PhD in political sciences. Stavropol, 2004. P. 120.

2 Masalov A.G. The Russian Cossacks: sociopolitical institutionalization in modern conditions: thesis of Grand PhD in political sciences. Stavropol, 2004. P. 122.
Host was being represented mostly by the Kalmyks. At the same time former soviet citizens who had left abroad after the World War II sometimes were joining the Cossack communities as natives from the Cossack regions not as hereditary Cossacks. The research of the Cossackemigrants in the second half of the XX century becomes much more difficult because of new problems. For example part of the Cossacks and their descendants after taking new citizenship gradually were being assimilated and losing their former identity.

Thus we can state that the unique character of the Cossacks as sociohistorical phenomenon does not allow us both to create the single and coherent theory of its genesis and even to give some clear definition.

Such state of affairs has also affected the current position of the Cossacks both in Russia and abroad. This gives to the Cossack Diaspora special features that make it fundamentally different from the other communities.

What is the Cossacks abroad nowadays? The Cossack Diaspora has been formed from the descendants of Cossacks emigrated in 1920, Cossacks (and their children) who left homeland in 1943-1945, Cossacks who went abroad in 1960s, 1980-1990 and in the beginning of the new century. The Diaspora consists of different Cossack Hosts. But the Don and Kuban Cossacks are more united. At the same time even they haven't succeeded the whole social organism abroad. Up to the present time some of the Cossack organizations are in conflict with each other.

The revival of the Cossacks in Russia breathed fresh spirit into the Cossack organizations and communities abroad. There is a tendency of joining forces on the development of Cossack culture, preserving Cossack traditions and uniting different Cossack organizations. However 
we can see also fence-mending between the Cossack communities in Russia.

The example of such fence-mending is the cooperation between the Kuban Cossack community "The Kuban Cossack Host" with its center in Krasnodar (Russia) and the Kuban Cossack Host abroad with the center in Howell (USA).

These Cossack communities for several times have sent the delegations to each other and participated in a number of joint activities. They mutually organized the return of the Cossack Host regalia that had been exported during the Civil War in 1920 to its historical homeland. Also they passed to Kuban the archive and the library of the Kuban Cossack Host abroad. The significance of the activity of the Kuban Cossack Host abroad was also noted at the highest state level. The Ataman of the Kuban Cossack Host abroad A.M. Pevnev was awarded with the Order of Friendship under the Presidential Decree № 266 of 25.03.2013.

The Cossack communities abroad are trying to establish contacts and cooperation. Thus under the initiative of the Ataman of the All-Cossack Union of the Czech lands and Slovakia it is being organized the joint work of the Cossack communities situated in the territories of a number of European countries.

The aims for such contacts and associations have mostly cultural nature and appeal to contribute to the development of the Cossack movement both in Russia and abroad. The main difficulty in setting this cooperation is being determined by such factors like paucity of the Cossacks outside Russia, their oddness, difference in understanding of the priorities and objectives of the Cossacks. Still the topical issue is the self-identity of Cossacks. There is also questionable attitude to the Cossacks from the population of non-Cossack origin who certainly treats terms "Cossack" and "the Cossacks" in different ways. It is not occasional that such organization like The Cossack Congress of America declares that "The real and ultimate objective of the Cossack Congress in America is recognition of Cossacks as the nation of the United Nations Organization". ${ }^{1}$

In general we can state the fact that the Cossack Diaspora being a component of the Russian émigré is at the same time differs from the last one. The Cossack Diaspora is the unique phenomenon both in the history of the Russian émigré and countries of their residence. This phenomenon deserves not only its research but also can become one of the channels of interaction of the representatives of socio-political and socio-cultural forces in Russia and outside of its borders.

Key words: Cossacks, emigration, Cossack emigré, Cossack-emigrants
1 The objective of the Cossack Congress in America. http://kazaksusa.com/node/563 (30.03.2014) 


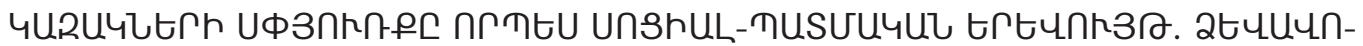

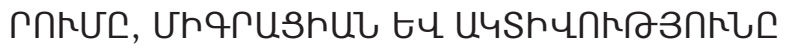

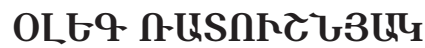

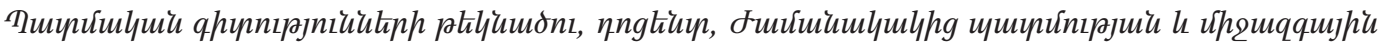

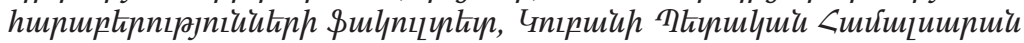

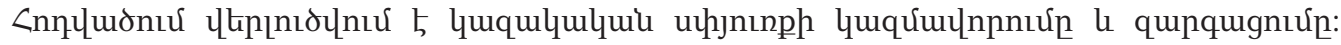

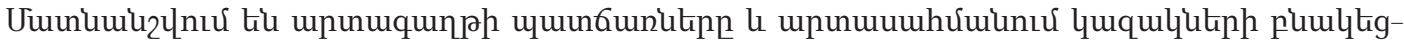

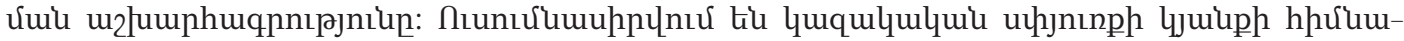

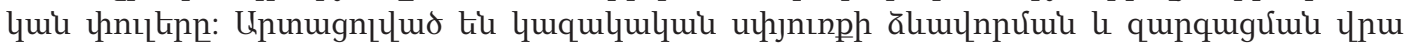

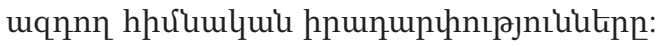

\section{КАЗАЧЬЕ ЗАРУБЕЖЬЕ КАК СОЦИАЛЬНО-ИСТОРИЧЕСКОЕ ЯВЛЕНИЕ: ФОРМИРОВАНИЕ, МИГРАЦИЯ И АКТИВНОСТЬ}

\section{ОЛЕГ РАТУШНЯК}

Кандидат исторических наук, доиент; доцент/докторант кафедры новой, новейшей истории и межсународных отношений Кубанского государственного университета

В статье проанализировано образование и развитие казачьего зарубежья. Показаны причины эмиграции и география расселения казаков за границей. Исследованы основные этапы жизни казачьего зарубежья, отражены основные события, повлиявшие на процесс формирования и развития казачьей диаспоры. 